\title{
El alumno-adulto como categoría analítica: reflexiones para repensar las prácticas pedagógicas de los docentes de la EEMPA
}

\author{
Alejandro D. Rojas ${ }^{(1)}$
}

Palabras clave:

alumno adulto $\cdot$ prácticas pedagógicas .

representaciones $\cdot$ pensamiento crítico

Resumen. Hemos de partir del supuesto según el cual una parte importante de las prácticas educativas de los profesores dependen asiduamente de sus formas de concebir al adulto como sujeto de aprendizaje. En función de estas representaciones, se piensan y organizan las interacciones institucionales y las modalidades didáctico-pedagógicas de la enseñanza en el aula. No siempre los docentes revisan sus concepciones más profundas y los posibles impactos de éstas en la propia tarea educativa; de ahí la importancia de desocultar significados y sentidos para reflexionar acerca de los diversos roles que se le asignan a la escuela y al conocimiento escolar.

Para ello, estimamos necesario convertir la expresión de «alumno-adulto», que comúnmente se usa, en un concepto con fuerza heurística, que permita aproximarnos al análisis propuesto. En el presente artículo planteamos una tipología en torno al alumno-adulto como categoría analítica, con el propósito de ensayar algunas reflexiones acerca de las orientaciones de las prácticas pedagógicas de los docentes que se desempeñan en la EEMPA.

(1) Profesor en Historia, egresado de la FHUC de la UNL. Docente del nivel secundario (escuelas medias, técnicas y para adultos), y del nivel terciario de la provincia de Santa Fe. Maestrando de la Maestría en Didácticas Específicas de la FHUC de la UNL. Cohorte 2008. Alumno de la Licenciatura en Historia de la FHUC de la UNL. E-mail: ale-rojas-55@hotmail.com.

\section{Keywords:}

adult pupil · pedagogic practices . representations $\cdot$ critical thought

Abstract. We have to depart from the supposition according to which one departs importantly from the educational practices of the teachers they depend on his forms conceiving assiduous the adult as subject of learning. Depending on these representations, there are thought and organize the institutional interactions and the didactic-pedagogic modalities of the education in the classroom.

Not always the teachers check his deeper conceptions and the possible impacts of these in the own educational task; of there the importance of des-to conceal meanings and senses, to think brings over of the diverse roles that assign him to the school and to the school knowledge.

For it, we estimate necessarily to turn the expression of "pupil-adult" who commonly uses, in a concept strongly heuristic, that allows to bring us near to the proposed analysis. In the present article we raise a typology concerning the pupil-adult as analytical category, with the intention of testing some reflections it brings over of the orientations of the pedagogic practices of the teachers who get out of a jam themselves in the EEMPA. 